\title{
Correction to: Qualitative description of the submission and agonistic behavior of the Spix's Macaw (Cyanopsitta spixii, Spix 1824), with special reference to the displacement displays
}

\author{
Vladislav Marcuk $^{1}$ (D) Cromwell Purchase ${ }^{1} \cdot$ Donovan de Boer $^{1} \cdot$ Marcellus Bürkle $^{2} \cdot$ Katrin Scholtyssek $^{1}$
}

Published online: 31 December 2020

(c) The Author(s) 2020

\section{Correction to: Journal of Ethology (2020) 38:253-270 https://doi.org/10.1007/s10164-020-00650-6}

The article Qualitative description of the submission and agonistic behavior of the Spix's Macaw (Cyanopsitta spixii, Spix 1824), with special reference to the displacement displays, written by Vladislav Marcuk, Cromwell Purchase, Donovan de Boer, Marcellus Bürkle, Katrin Scholtyssek, was originally published Online First without Open Access. After publication in volume 38, issue 3, page 253-270 the author decided to opt for Open Choice and to make the article an Open Access publication. Therefore, the copyright of the article has been changed to $($ The Author(s) 2020 and the article is forthwith distributed under the terms of the Creative Commons Attribution 4.0 International License, which permits use, sharing, adaptation, distribution and reproduction in any medium or format, as long as you give appropriate credit to the original author(s) and the source, provide a link to the Creative Commons licence, and indicate if changes were made. The images or other third party material in this article are included in the article's Creative Commons licence, unless indicated otherwise in a credit line to the material. If material is not included in the article's
Creative Commons licence and your intended use is not permitted by statutory regulation or exceeds the permitted use, you will need to obtain permission directly from the copyright holder. To view a copy of this licence, visit http:// creativecommons.org/licenses/by/4.0/

The original article has been corrected.

Open Access This article is licensed under a Creative Commons Attribution 4.0 International License, which permits use, sharing, adaptation, distribution and reproduction in any medium or format, as long as you give appropriate credit to the original author(s) and the source, provide a link to the Creative Commons licence, and indicate if changes were made. The images or other third party material in this article are included in the article's Creative Commons licence, unless indicated otherwise in a credit line to the material. If material is not included in the article's Creative Commons licence and your intended use is not permitted by statutory regulation or exceeds the permitted use, you will need to obtain permission directly from the copyright holder. To view a copy of this licence, visit http://creativecommons.org/licenses/by/4.0/.

Publisher's Note Springer Nature remains neutral with regard to jurisdictional claims in published maps and institutional affiliations.

The original article can be found online at https://doi.org/10.1007/ s10164-020-00650-6.

Vladislav Marcuk

vladislav.marcuk@googlemail.com

1 Association for the Conservation of Threatened Parrots e. V., Hindenburgstraße 37, Hannover, Germany

2 Tierarztpraxis Dr. Bürkle, Eisenbahnstraße 32,

77855 Achern, Germany 